\title{
Eneolithic copper smelting slags in the Eastern Alps: Local patterns of metallurgical exploitation in the Copper Age
}

\author{
G. Artioli ${ }^{\text {a, }}$, I. Angelini ${ }^{\text {a }}$, U. Tecchiati ${ }^{b}$, A. Pedrotti ${ }^{c}$ \\ a Dipartimento di Geoscienze, Università degli Studi di Padova, Padova, Italy \\ ${ }^{\mathrm{b}}$ Ufficio Beni Archeologici, Provincia Autonoma di Bolzano, Bolzano/Bozen, Italy \\ ${ }^{\mathrm{c}}$ Dipartimento di Filosofia, Storia e Beni Culturali, Università degli Studi di Trento, Trento, Italy
}

\section{A R T I C L E I N F O}

\section{Article history:}

Received 22 February 2015

Received in revised form

4 August 2015

Accepted 16 August 2015

Available online 19 August 2015

\section{Keywords:}

Copper metallurgy

Eastern Alps

Smelting slags

Eneolithic

Lead isotope analysis

\begin{abstract}
A B S T R A C T
A number of slags of all known sites in the Italian Eastern Alps showing occurrences of copper smelting activities in the Copper Age have been characterized by lead isotope analysis. All the investigated smelting slags from Trentino (Romagnano Loc, La Vela, Gaban, Acquaviva di Besenello, Montesei di Serso) and Alto Adige/Sud Tyrol (Millan, Gudon, Bressanone Circonvallazione Ovest) have been recently characterized by thorough mineralogical, petrographical and chemical analysis and demonstrated to be the product of copper smelting activities of chalcopyrite-based mineral charges, with an immature technological extraction process referred as the "Chalcolithic" smelting process. Revision of the available radiocarbon dates show that the metallurgical activities pertaining to the analysed slags can be attributed to the third millennium BC. The lead isotope analysis indicates clearly that the mineral charge use for the smelting process was extracted from nearby mineral deposits. The detailed analysis of the spatial distribution of ores and slags allows for the first time to define the local organization of the metallurgical operations.
\end{abstract}

() 2015 Elsevier Ltd. All rights reserved.

\section{Introduction}

The Italian Eastern Alps are a well-known source of copper metal that was exploited since prehistory, possibly since Late Neolithic times. Due to the large amount of archeological evidence, especially the widespread and abundant occurrence of copper smelting slags (e.g. Cierny et al., 2004; Cierny, 2008), the climax of the mining activities and copper production is currently attributed to the Recent and Final Bronze Age (Marzatico, 1997; Weisgerber and Goldenberg, 2004), and subsequently to Roman and Middle Age times, when large groups of German miners moved to some of the Alpine valleys to organize and carry out the mining operations (Šebesta, 2000; Zammatteo, 2009). However the copper metal was circulating well before the Bronze Age, as the archeological evidence clearly shows (Pedrotti, 2002: p. 213): metal objects were circulating at least from the late neolithic (Angelini et al., 2013) and a number of Copper Age sites in the Trentino and Alto Adige areas yield evidence of smelting activities in the form of metallurgical slags, tuyeres, a multitude of copper objects including the Iceman's

\footnotetext{
* Corresponding author.

E-mail address: gilberto.artioli@unipd.it (G. Artioli).
}

axe, and a few occurrences of pyrotechnological installations (Perini, 1989; Pedrotti, 2002; Pearce, 2007).

The focus of the present investigation is to characterize the isotopic signal of the known Eneolithic smelting slags and to compare the measured lead isotope ratios with the signal of the copper deposits in the Eastern Alps (Nimis et al., 2012; Artioli et al., 2013), in order to pinpoint which deposits were actually exploited in the Copper Age, and possibly outline the local organization of the metallurgical activities.

\section{Slag samples: selection and characterization}

The slag samples to be investigated were selected based on (1) their secure occurrence in archaeological sites dated to the 3rd millennium BC, and (2) previous results of mineralogical, petrographic, and chemical studies on the slags confirming that they are indeed the product of copper smelting activities.

Table 1 lists the sites where the investigated copper smelting slags were located together with the related archeological literature. Fig. 1 shows the geographical distribution of the sites, all located in the Trentino and Alto-Adige areas.

The sites are clustered in three main areas: 
Table 1

List of sites yielding the investigated copper smelting slags, with the related references of previous archaeological and archaeometric work.

\begin{tabular}{|c|c|c|}
\hline Locality & Area & References \\
\hline Millan & Isarco Valley, Alto Adige & Tecchiati 2009, Colpani et al., 2009, Angelini et al., 2013 \\
\hline Gudon & Isarco Valley, Alto Adige & Colpani et al., 2009, Angelini et al., 2013 \\
\hline Bressanone Circonvallazione Ovest & Isarco Valley, Alto Adige & Angelini et al., 2013 \\
\hline Gaban & Adige Valley, Trentino & Cattoi et al., 1995, Cattoi et al. 1997, D'Amico et al., 1998, Artioli et al., 2009 \\
\hline La Vela & Adige Valley, Trentino & Fasani 1988, Perini 1989, Metten 2003, Artioli et al., 2009 \\
\hline Acquaviva di Besenello & Adige Valley, Trentino & Cattoi et al., 1995, Cattoi et al. 1997, D'Amico et al., 1998, Pedrotti 2002, Metten 2003, Artioli et al., 2009 \\
\hline Romagnano & Adige Valley, Trentino & Perini 1971, Perini 1989, Cattoi et al., 1995, Cattoi et al. 1997, Metten 2003, Artioli et al., 2009 \\
\hline Montesei di Serso & Valsugana, Trentino & Perini 1989, Metten 2003, Artioli et al., 2009 \\
\hline
\end{tabular}

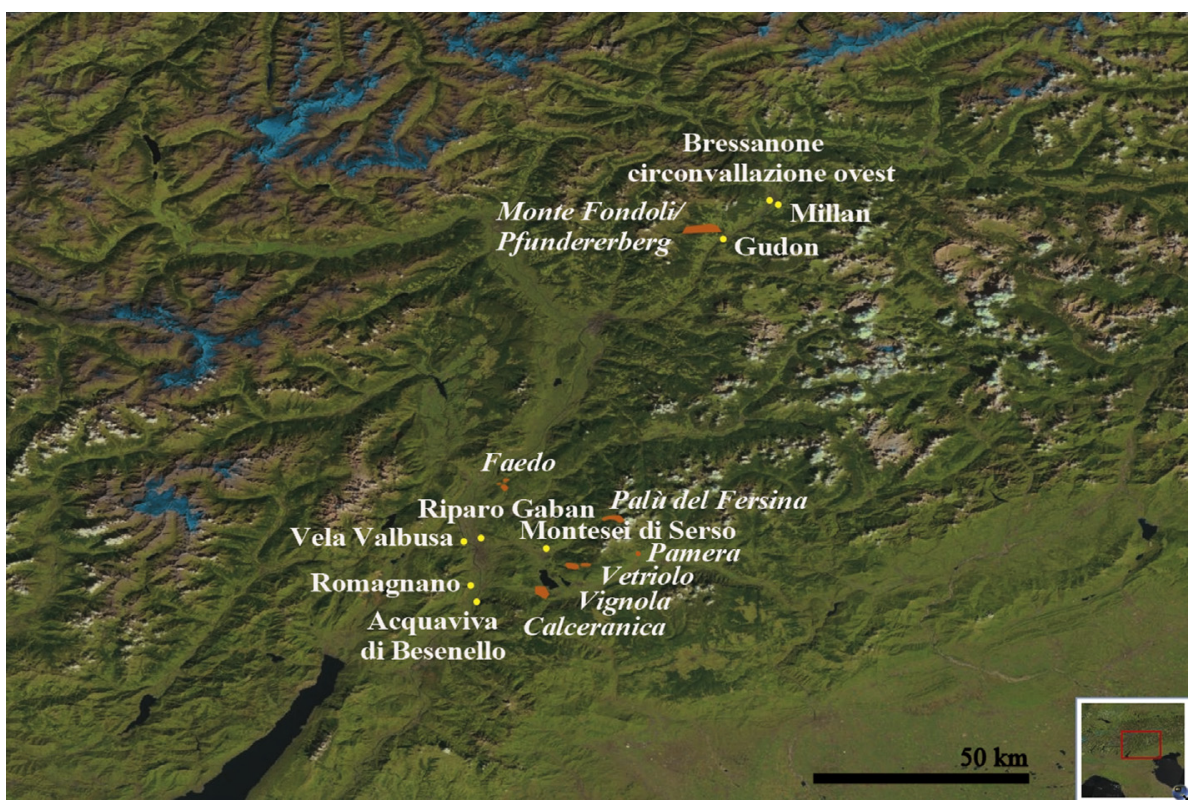

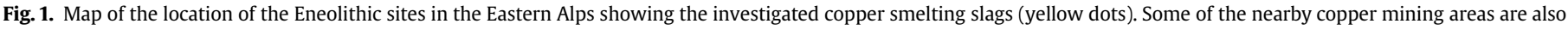

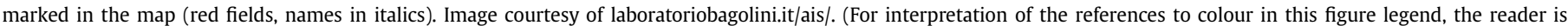
referred to the web version of this article.)

a) Millan, Gudon, and the site of Circonvallazione ovest are all located in the Isarco river valley near the city of Bressanone/ Brixen

b) Romagnano Loc and La Vela are located in proximity of the Western bank of the Adige River, whereas Gaban, and Acquaviva di Besenello are located in proximity of the Eastern banks of the river in the outskirts of the city of Trento

c) Montesei di Serso is located in the upper Valsugana Valley near the city of Pergine, again located in the Eastern area the Adige River.

The common feature of all these sites is the location at low altitude, near the bottom of the valley, in close proximity to the river and, presumably, to the coeval settlements. The archaeological occurrences of the Trentino slags and their dates have been extensively discussed by Pearce (2007): the critical revision of the available dates indicate that the start of the metallurgical activities at Gaban and Acquaviva can be attributed to the early 3rd millennium $\mathrm{BC}$, whereas the analysed slags from the other sites cluster around the second half of the 3rd millennium $B C$. The recent dates obtained on the Alto Adige sites (Millan, Gudon) confirm this chronology (Angelini et al., 2013).

All samples were previously thoroughly characterized by minero-petrographical and chemical analysis by X-ray powder diffraction, optical microscopy, and electron microscopy with energy dispersive spectroscopy (Artioli et al., 2009; Colpani et al., 2009). The common features of all slags are here summarized:

- Very heterogeneous and coarse texture (Fig. 2)

- Presence of primary sulphide relics (chalcopyrite) with only incipient reactions (Fig. 3)

- Abundant unreacted quartz

- Presence of typical slag minerals formed during smelting, especially fayalitic olivine, but also pyroxenes (see Colpani et al., 2009)

- Presence of abundant wuestite, frequently dendritic (Fig. 4) or agglomerated

- Presence of copper or matte droplets, frequently intermixed with magnetite

The overall features, such as the coarse texture, the presence of wuestite and magnetite even in the same slag and the occurrence of poorly reacted sulphides indicate an incomplete process of copper extraction and poorly controlled temperature and oxygen fugacity conditions. The slags never underwent a complete melting stage and the process of copper extraction was rather inefficient. These features altogether have been taken as evidence of a technologically non-standardized process of copper extraction, referred to as the "Chalcolithic" process (Pearce, 2007; Bourgarit, 2007). The observed mineralogical ad textural features are compatible with 

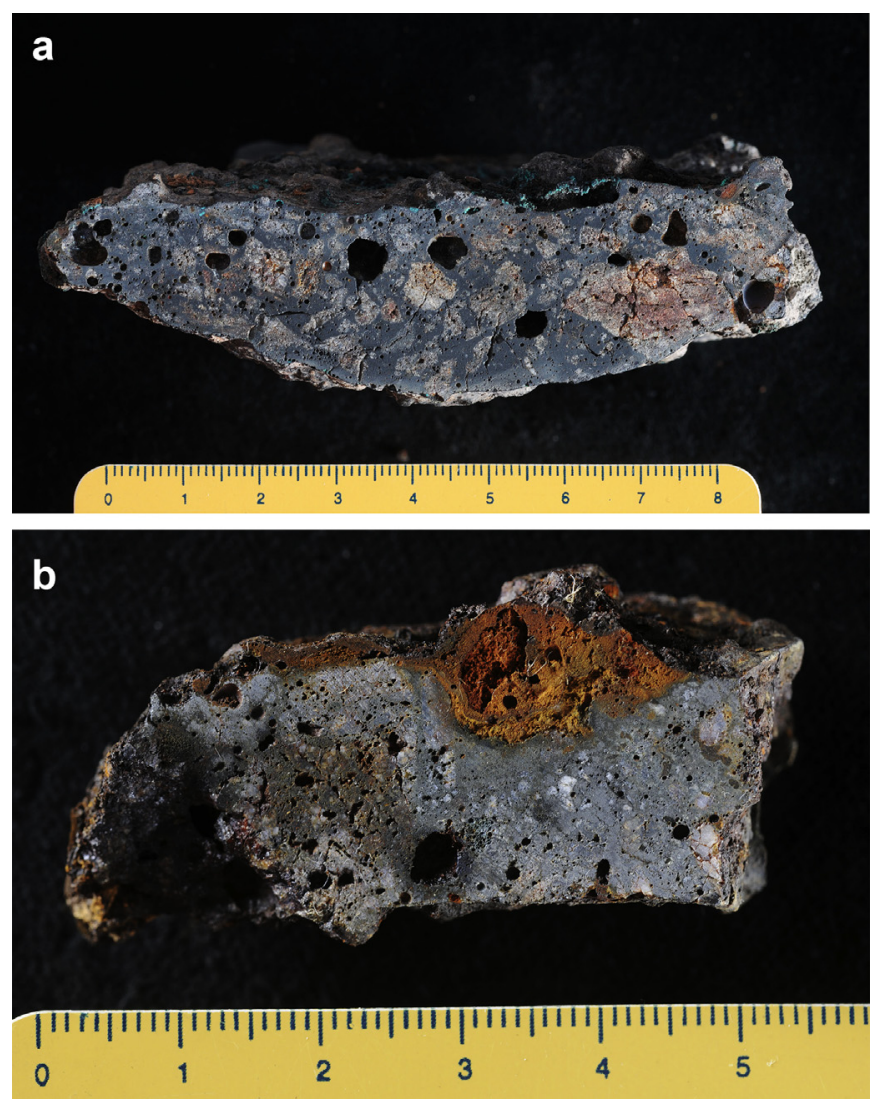

Fig. 2. Macroscopic images showing the coarse texture common of all the investigated Eneolithic slags: (a) slag sample from Riparo Gaban, Trentino (sett. IV C6); (b) slag sample from Millan, Alto Adige.

the age attributed to the sites, and are totally different from those observed in the Late Bronze Age slags found in the same area (Cierny, 2008; Anguilano et al., 2002; Addis et al., 2015).

One copper fragment was also recovered in the Millan site amidst the large amount of smelting slags (Fig. 5). Since it represent a very rare occurrence, and further evidence of the metallurgical activities, it was also analysed and compared with the slag data.

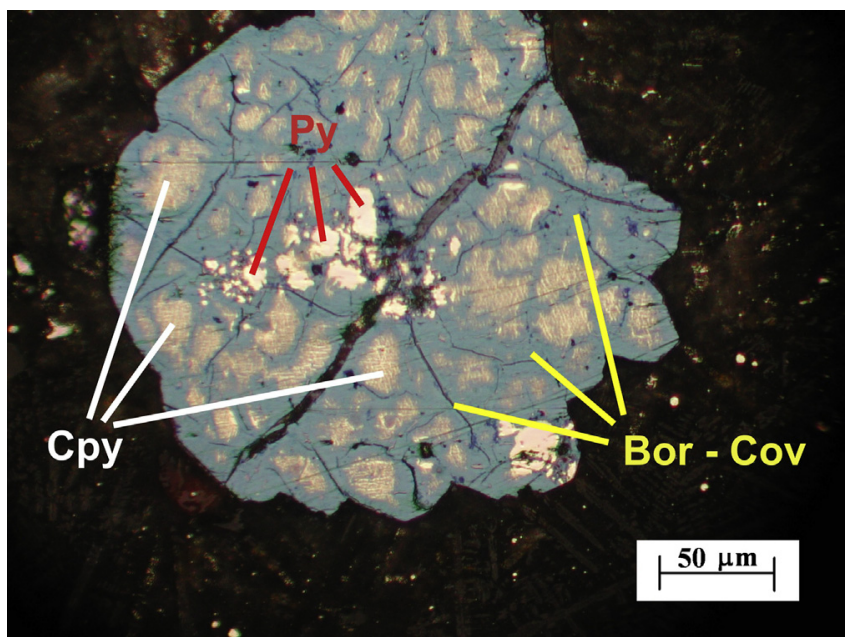

Fig. 3. Partially reacted primary sulphide in a slag sample from Riparo Gaban, Trentino (sett. IV C6). Optical microscopy, reflected light, the diameter of the sulphide grain is approximately $350 \mu \mathrm{m}$. Py = pyrite, Cpy = chalcopyrite, Bor-Cov $=$ secondary sulphide of bornite-covelline composition.

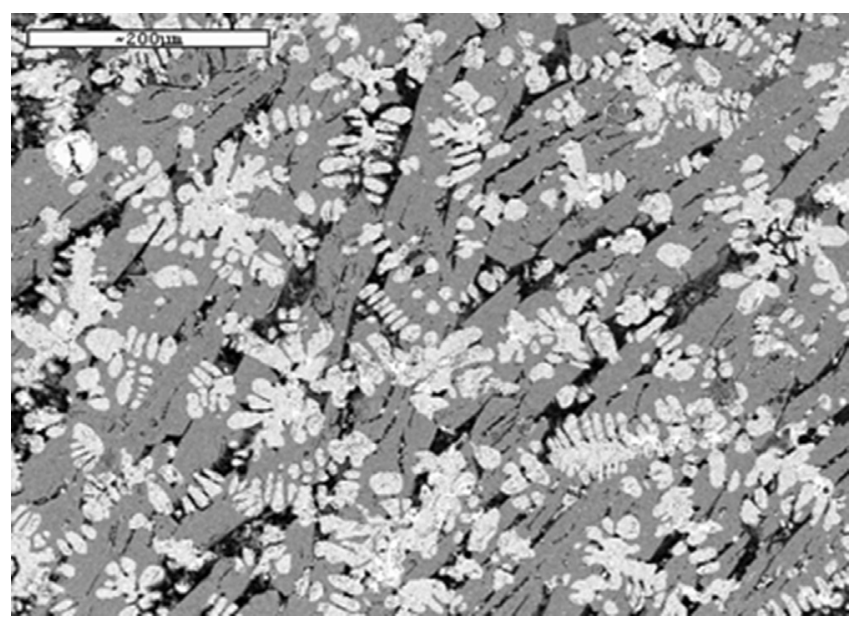

Fig. 4. Wuestite dendrites in the fayalitic matrix. Slag sample from Montesei di Serso, Trentino. Scanning electron microscopy, backscattered electron image, reference bar is $200 \mu \mathrm{m}$.

\section{Lead isotope measurements}

The slag samples were characterized in thin section by optical microscopy under transmitted and reflected light and by X-ray powder diffraction. A portion of each sample rich in fayalitemagnetite-sulphides was gently crushed and adequate amount of fragments was separated by handpicking under a binocular microscope. For the most part the selected fragments consist of fayalite-magnetite residues with microscopic inclusions of copper and sulphidic matte. In some cases small inclusions of partially reacted sulphide ores are present.

The separates (10-100 mg) were dissolved in aqua regia by high-pressure microwave digestion in sealed PTFE vessels. The dissolved lead was purified using the $\mathrm{Sr} \_$SpecTM resin (EIChroM Industries; Horwitz et al., 1992), following the same procedure described in Villa (2009). About 100 mL of Sr_SpecTM resin are filled in a 3-mm diameter hand-made PTFE column. The height to width ratio is approximately 4 . The sample solution is loaded in $0.5 \mathrm{~mL} 1 \mathrm{M} \mathrm{HNO}_{3}, 1.5 \mathrm{~mL}$ of which is also used to wash out the matrix metals, while $\mathrm{Pb}$ is very strongly retained on the resin. $\mathrm{Pb}$ is

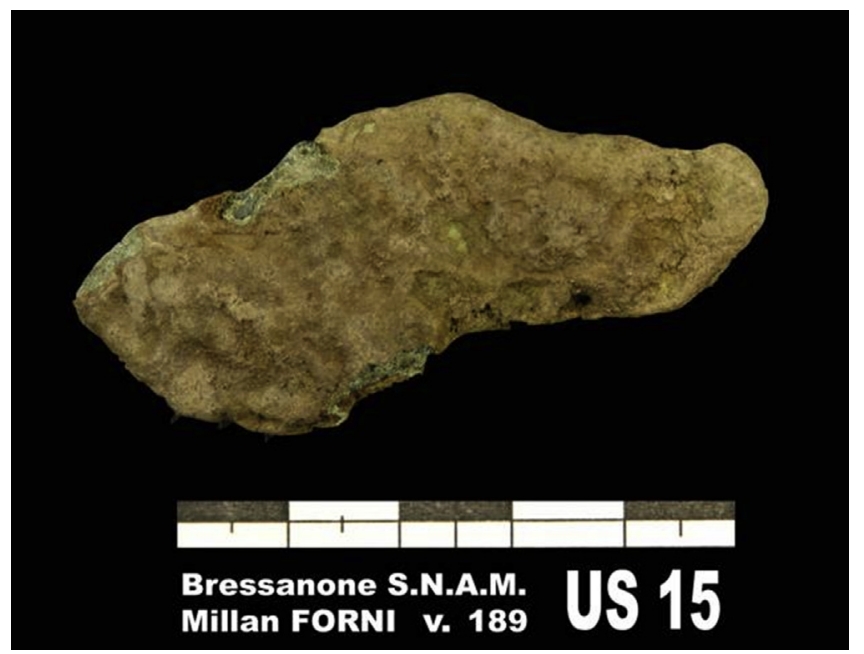

Fig. 5. The copper fragment found in association with the copper smelting slags at the Millan site, Alto Adige (US-15). It is one of the rare pieces of metals ever found together with the copper smelting residues. 
Table 2

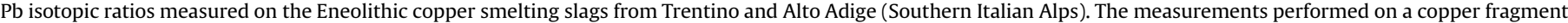
found in association with the Millan slags are also reported (sample BFO60-15).

\begin{tabular}{|c|c|c|c|c|c|c|c|}
\hline Locality & Sample & ${ }^{206} \mathrm{~Pb} /{ }^{204} \mathrm{~Pb}$ & $2 \sigma$ & ${ }^{207} \mathrm{~Pb} /{ }^{204} \mathrm{~Pb}$ & $2 \sigma$ & ${ }^{208} \mathrm{~Pb} /{ }^{204} \mathrm{~Pb}$ & $2 \sigma$ \\
\hline Bressanone & BX-A4 & 18,298 & 0.001 & 15,682 & 0.002 & 38,539 & 0.006 \\
\hline Bressanone & BX-P1 & 18,271 & 0.002 & 15,682 & 0.002 & 38,516 & 0.007 \\
\hline Millan & BFO104-18 & 18,270 & 0.002 & 15,688 & 0.003 & 38,531 & 0.008 \\
\hline Millan & BFO60-15 & 18,265 & 0.001 & 15,690 & 0.002 & 38,540 & 0.007 \\
\hline Millan & BFO60-15 & 18,279 & 0.003 & 15,693 & 0.002 & 38,545 & 0.005 \\
\hline Gudon & US12A & 18,265 & 0.003 & 15,685 & 0.001 & 38,525 & 0.006 \\
\hline Gudon & US14A & 18,281 & 0.002 & 15,686 & 0.002 & 38,532 & 0.005 \\
\hline Gudon & US14C -2 & 18,287 & 0.002 & 15,699 & 0.002 & 38,573 & 0.006 \\
\hline Gudon & US14C - 1 & 18,276 & 0.003 & 15,687 & 0.003 & 38,533 & 0.004 \\
\hline Gudon & US14D & 18,276 & 0.003 & 15,690 & 0.002 & 38,543 & 0.006 \\
\hline Gudon & US15 & 18,265 & 0.002 & 15,684 & 0.002 & 38,517 & 0.007 \\
\hline La Vela & LV15 & 18,298 & 0.004 & 15,682 & 0.003 & 38,539 & 0.006 \\
\hline La Vela & LV 18 & 17,936 & 0.002 & 15,642 & 0.002 & 38,141 & 0.006 \\
\hline La Vela & LV 9 & 17,919 & 0.002 & 15,642 & 0.002 & 38,135 & 0.007 \\
\hline La Vela & LV 5 & 17,909 & 0.003 & 15,643 & 0.003 & 38,130 & 0.008 \\
\hline Montesei & MS 1 & 18,226 & 0.005 & 15,667 & 0.005 & 38,461 & 0.015 \\
\hline Montesei & MS 3 & 18,262 & 0.007 & 15,686 & 0.006 & 38,523 & 0.014 \\
\hline Montesei & MS 11 & 18,229 & 0.007 & 15,654 & 0.008 & 38,446 & 0.027 \\
\hline Montesei & MS 11 replica & 18,238 & 0.001 & 15,664 & 0.002 & 38,473 & 0.005 \\
\hline Gaban & GAB 1 (C6) & 18,110 & 0.001 & 15,658 & 0.001 & 38,344 & 0.004 \\
\hline Gaban & GAB 2 & 17,903 & 0.002 & 15,643 & 0.002 & 38,120 & 0.006 \\
\hline Gaban & GAB 3 & 17,896 & 0.002 & 15,643 & 0.002 & 38,114 & 0.007 \\
\hline Romagnano & ROM 1 & 17,988 & 0.003 & 15,647 & 0.002 & 38,191 & 0.006 \\
\hline Romagnano & ROM 13 & 17,921 & 0.002 & 15,641 & 0.002 & 38,131 & 0.007 \\
\hline Acquaviva & ACQ 1 & 17,911 & 0.002 & 15,640 & 0.002 & 38,119 & 0.007 \\
\hline Acquaviva & ACQ 2 & 18,195 & 0.002 & 15,661 & 0.002 & 38,431 & 0.007 \\
\hline Acquaviva & ACQ 3 & 17,940 & 0.001 & 15,650 & 0.002 & 38,171 & 0.003 \\
\hline
\end{tabular}

a Measurement performed in Bern.

b Measurement performed in London (courtesy of W. Müller).

then eluted with $3 \mathrm{~mL} 0.01 \mathrm{M} \mathrm{HNO}_{3}$ and is ready for analysis. Lead isotope analyses were performed with a Multi-Collector-ICP-MS (Nu Plasma II) at the Institut für Geologie, University of Bern (Switzerland). The sample solution was ionized by introducing it into a $9000 \mathrm{~K}$ plasma. All elements were ionized simultaneously. Mass fractionation was monitored by adding a small quantity of $\mathrm{Tl}$, which has a known ${ }^{203} \mathrm{Tl} /{ }^{205} \mathrm{Tl}$ ratio, is ionized together with and fractionated by the same mechanism as $\mathrm{Pb}$, and does not interfere with $\mathrm{Pb}$ isotope measurements. Calibration was carried out using the NIST SRM 981 international standard. The results are reported in Table 2. Typical in-run relative uncertainties $(2 \mathrm{~s})$ on ${ }^{206} \mathrm{~Pb} /{ }^{204} \mathrm{~Pb}$, ${ }^{207} \mathrm{~Pb} /{ }^{204} \mathrm{~Pb}$, and ${ }^{208} \mathrm{~Pb} /{ }^{204} \mathrm{~Pb}$ isotope ratios were smaller than $0.2 \%$. The external reproducibility on the NIST SRM 981 reference material amounted to $\pm 0.15 \%$ o (2s), very similar to the individual inrun precision on unknown samples. Total errors reported in Table 2 were calculated by normal error propagation taking into account both in-run uncertainties and dispersion of repeated measurements on NIST SRM 981 during the same analytical session.

A small fragment of the copper fragment found at Millan (sample BFO60-15, Fig. 5) was also analysed in Bern using the same protocols. An earlier measurement performed at the Royal Holloway, University of London by Dr. Wolfgang Müller on the same object is also reported for comparison purposes (Table 2).

\section{Results and discussion}

The $\mathrm{Pb}$ isotope ratios measured on the Eneolithic copper smelting slags from Trentino and Alto Adige (Table 2) can be directly compared to the available data on copper ores from the Southern Eastern Alps (Nimis et al., 2012). The data are shown in Fig. $6 a$ and $b$.

Apart from one slag sample from Gaban, which is located midway between the two major field of Southern Alpine copper deposits, as a first approximation all other slag data cluster in close proximity of the reported LI ore data. This is no surprise, since it is of course expected that the sulphidic ores used for metal extraction must derive from nearby sources. However, the availability of geologically and geographically well-resolved data for the ores permits a very detailed analysis of the pattern of mine exploitation in the areas around the smelting sites.

It can be clearly observed that the slags from Romagnano, La Vela, Gaban and Acquaviva sites, all located in the Adige Valley, show a close affinity to the ores of the Pre-Variscan massive deposits related to the Hercinian basement. These are mostly located in proximity of the Valsugana fault, and the major mine is that of Calceranica (Fig. 7). On the other hand the slags of Montesei di Serso and all the Alto Adige sites (Bressanone, Gudon, Millan) show a clear relationship to the Post-Variscan sulphide ores related to Permian and Triassic volcanics. Specifically, the Montesei slags show close affinity to the polysulphidic ores present in the Val dei Mocheni (Fig. 7), whereas the Alto Adige slags are evidently related to the ores of the Monte Fondoli area, near Chiusa (Fig. 8). The data obtained on the copper fragment associated to the Millan slags are also internally consistent and fit perfectly with the slags data and the Monte Fondoli ores.

The data indicate that in the Alto Adige area, where only one major deposit occurs (Monte Fondoli), these ores were supplying the chalcopyritic charge for all the metallurgical activities along the Isarco Valley. Again it should be noted that all slag-producing sites are located not far from the river, at low altitude.

In the Trentino area, where many ore sources are available, a pattern of exploitation seem to appear: the metallurgical smelting sites located along the Adige River Valley obtained the chalcopyritic charge essentially from the mine of Calceranica, easily reachable through at least three easy routes, the road though Folgaria, the Valsorda road, and the main entrance to the Valsugana Valley, just west of Trento. Interestingly, the slag sites are located almost 

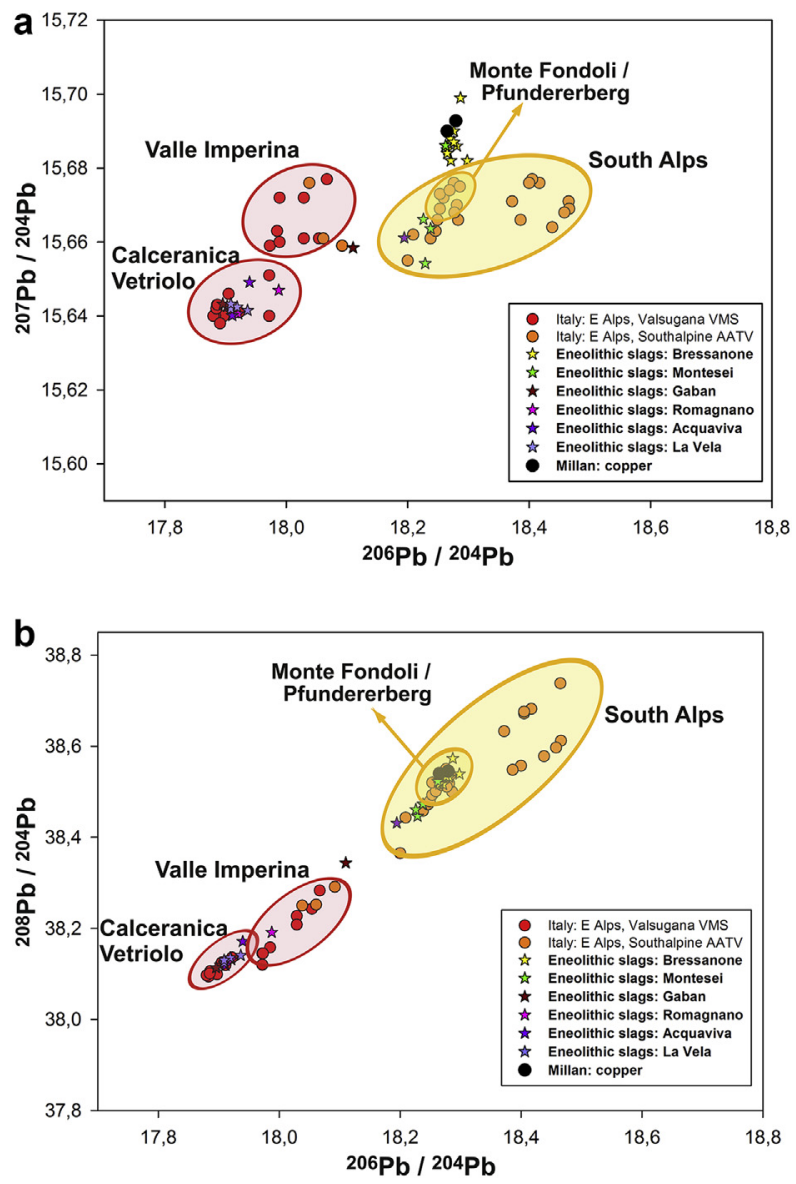

Fig. 6. Lead isotope ratios in the analysed Eneolithic copper smelting slags from Trentino and Alto Adige (stars), compared to the available data for copper ores (circles). The ore deposits have been divided into two main groups: the pre-Variscan massive ores related to the Hercinian basement and located in proximity of the Valsugana fault (red circles: valsugana VMS volcanogenic massive sulphides), the post-Variscan ores mostly constituted by polymetallic sulphides related to Permo-Triassic volcanics (orange circles: broadly labelled as Southalpine deposits from Alto Adige, Trentino, and Veneto AATV). (For interpretation of the references to colour in this figure legend, the reader is referred to the web version of this article.)

exactly at the outlet of these three roads into the Adige valley. Conversely the Montesei site, located near Pergine at the bottom of the Valsugana Valley, obtained the sulphidic ore exclusively from the Valle dei Mocheni, despite being conveniently located on the opposite side of the Valley with respect to the Calceranica mine. It looks that the Valsugana Valley acted as the boundary for the two independent metallurgical districts. This implies local control of the territory and of the ore resources.

It also proves interesting to compare the slag $\mathrm{Pb}$ isotope data with the available data on coeval objects (Fig. 9). The plots show clearly that the local ores linked to the smelting slags that were exploited for the copper production in the Southern Alps in the 3rd millennium $B C$ are also the source for a substantial part of the circulating copper objects in the region. These include several of the objects found in the Col del Buson hoard (Angelini et al., 2011), the awl (from Cellore, Illasi) and the copper ingot (from Cisano, Bardolino) analysed by Pernicka and Salzani (2011), and the two axes from Serravalle (Tecchiati, 1991). The published objects from Tyrol and Serbia show a markedly different signal, mostly related to the Serbian deposits (Höppner et al., 2005; Pernicka et al., 1993, 1997). Only one of the Italian objects (a small metal ring from the Col del Buson hoard) seems to be related to the Balkan ores.

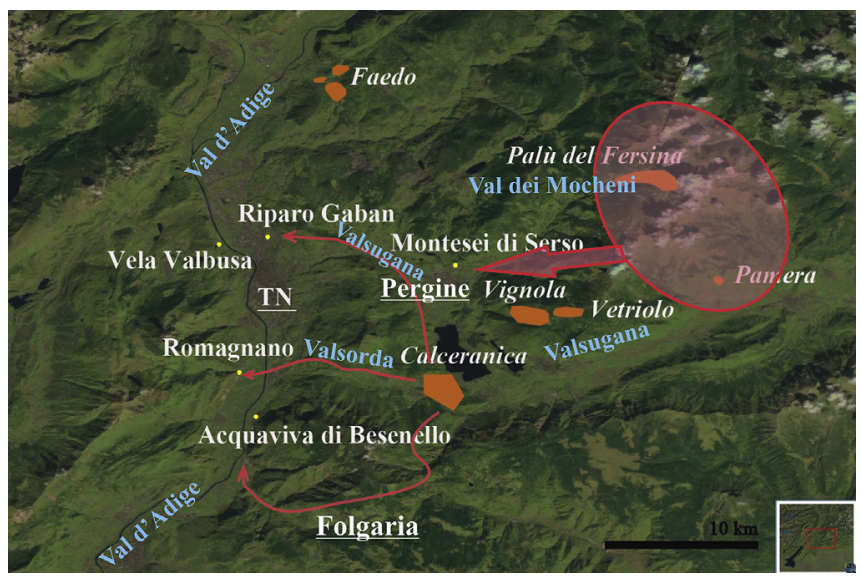

Fig. 7. Location of the occurrences of the analysed Eneolithic copper smelting slags in Trentino (yellow dots), together with the nearby ore sources matching the LI signa (orange fields, names in italics). The localities and geographical features cited in the text are reported (Town names are underscored). Image courtesy of laboratoriobagolini.it/ais/. (For interpretation of the references to colour in this figure legend, the reader is referred to the web version of this article.)

\section{Conclusions}

The lead isotope analysis of the copper smelting slags from all known metallurgical sites in Trentino and Alto Adige during the 3rd millennium $B C$ show a consistent pattern relating the sulphidic ore sources and the smelting locations. The Monte Fondoli deposit is the only source supplying the smelting sites in Alto Adige, all located along the bottom of the Isarco River Valley. In Trentino the major copper ore deposits are located along or nearby the Valsugana Valley, and the valley itself seem to represent a major geographical boundary between independently managed mining districts.

Although copper-based objects were circulating in the area well before the mid-Eneolithic, as testified by several metal finds (Pedrotti, 2002; Pearce, 2007), the substantial amount of slags produced during the 3rd millennium (i.e. several hundred kilograms at Milland and La Vela) indicate the start of the massive exploitation of ores in the Southern Alps and the systematic and well organized production of copper metal. Correspondingly, many of the objects circulating in the region result to be produced from Southern Alpine copper.

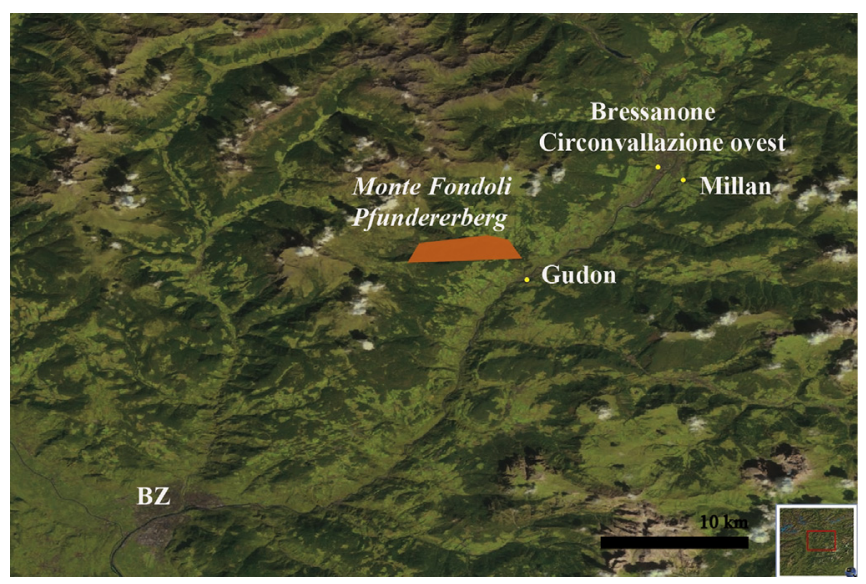

Fig. 8. Location of the occurrences of the analysed Eneolithic copper smelting slags in Alto Adige (yellow dots), together with the nearby ore source at Monte Fondoli (Pfundererberg, Chiusa) matching the LI signal (orange field, names in italics). Image courtesy of laboratoriobagolini.it/ais/. (For interpretation of the references to colour in this figure legend, the reader is referred to the web version of this article.) 

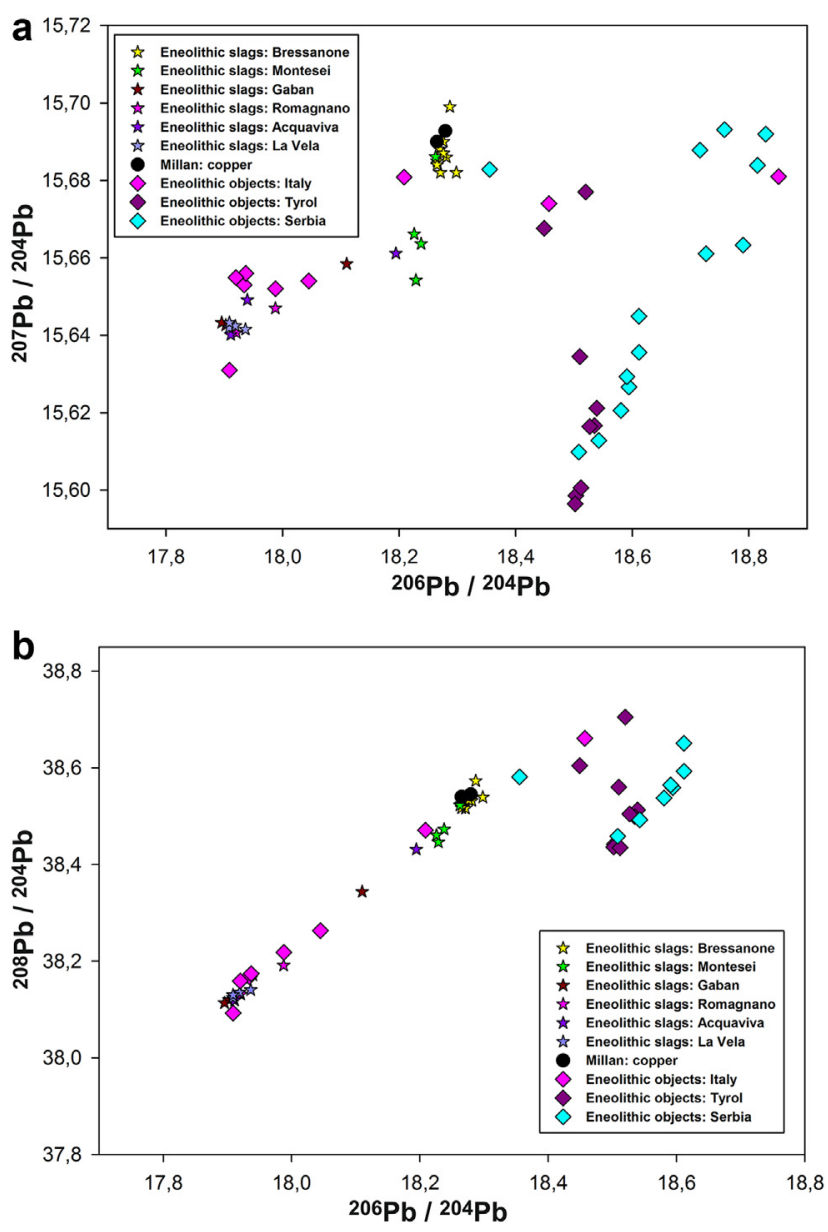

Fig. 9. Lead isotope ratios in the analysed Eneolithic copper smelting slags from Trentino and Alto Adige (stars), compared to the available data for late-Neolithic and Eneolithic objects (diamonds). The data for the objects from Northern Italy are from Angelini et al. (2011) and Pernicka and Salzani (2011). The data for the objects from Tyrol are from Höppner et al. (2005). The data for the Serbian objects are from Pernicka et al. (1993).

\section{Acknowledgements}

Ilaria Giunti, Anna Addis, and Caterina Canovaro helped at different stages in the sample preparation and MS measurements at the Institut für Geologie, Bern. The Museo di Storia Naturale, Trento kindly made the samples from Trentino available for the study. Dr. Wolfgang Müller allowed reporting of his measurement on sample BFO60-15.

\section{References}

Addis, A., Angelini, I., Nimis, P., Artioli, G., 2015. Late Bronze Age copper smelting slags from Luserna (Trentino, Italy): interpretation of the metallurgical process. Archaeometry. http://dx.doi.org/10.1111/arcm.12160 (in press).

Angelini, I. Artioli, G., Pedrotti, A., Tecchiati, U., 2013. . La metallurgia dell'età de Rame dell'Italia settentrionale con particolare riferimento al Trentino e all'Alto Adige. Le risorse minerarie e i processi di produzione del metallo. In: De Marinis, R.C. (Ed.), L'età del Rame: la Pianura Padana e le Alpi al tempo di Ötzi. Catalogo della mostra. Compagnia della Stampa Massetti Rodella editori, Brescia, pp. 101-116.

Angelini, I., Giunti, I., Artioli, G., 2011. Indagini archeometallurgiche su reperti dell'età del Rame della valle del Piave. Quad. Archeol. del Veneto XXVII, 107-115.

Anguilano, L., Angelini, I., Artioli, G., Moroni, M., Baumgarten, B., Oberrauch, H., 2002. Smelting slags from Copper and Bronze Age archaeological sites in Trentino and Alto Adige. In: D'Amico, C. (Ed.), Atti II Congresso Nazionale di Archeometria. Bologna 29 gennaio-1 febbraio 2002. Pàtron Editore, Bologna, pp. 627-638.

Artioli, G., Angelini, I., Burger, E., Bourgarit, D., 2009. Petrographic and chemica investigation of the earliest copper smelting slags in Italy: towards a reconstruction of the beginning of copper metallurgy. In: Proc. 2nd Intern. Conference "Archaeometallurgy in Europe 2007, Aquileia, 17-21 June 2007. Proc. CD. Printed in the Selected Papers Volume, AIM, Milano, pp. 12-20.

Artioli, G., Angelini, I., Nimis, P., Addis, A., Villa, I.M., 2013. Prehistoric copper metallurgy in the Italian Eastern Alps: recent results. Hist. Metall, 47, 51-59.

Bourgarit, D., 2007. Chalcolithic copper smelting. In: La Niece, S., Hook, D., Craddock, P. (Eds.), Metals and Mines. Studies in Archaeometallurgy. The British Museum-Archetype Publications, London, pp. 3-14.

Cattoi, E., D'Amico, C., Fabris, S., 1995. Studio petroarcheometrico di scorie di fusione della fine dell'Età del Bronzo e confronti con scorie dell'Età del Rame/Bronzo Antico in Trentino. Preistoria Alp. 31, 125-145.

Cattoi, E., D'Amico, C., Gasparotto, G., Girani, M., 1997. Petroarchaeometry of copper smelting slags in Trentino: provenance and process data. Preistoria Alp. 33, $151-154$.

Cierny, J., 2008. Prähistorische Kupferproduktion in den südlichen Alpen: region trentino orientale, Der Anschnitt, vol. 22. Bergbau-Museum, Bochum.

Cierny, J., Marzatico, F., Perini, R., Weisgerber, G., 2004. La riduzione del rame in località Acqua Fredda al passo del Redebus (Trentino) nell'età del Bronzo Recente e Finale. In: Weisgerber, G., Goldenberg, G. (Eds.), Alpenkupfer - Rame Delle Alpi. Der Anschnitt, vol. 17. Deutsches Bergbau Museum, Bochum, pp. 125-154.

Colpani, F., Angelini, I., Artioli, G., Tecchiati, U., 2009. Copper smelting activities at the Millan and Gudon Chalcolithic sites (Bolzano, Italy): chemical and mineralogical investigations of the archaeometallurgical finds. In: Moreau, J.F., Auger, R., Chabot, J., Herzog, A. (Eds.), Proc. ISA 2006, 36th Intern. Symposium on Archaeometry, Quebec City, Canada 2-6 May 2006, Cahiers d'archéologie du CELAT, n. 25, Série Archéometrie, n. 7. CELAT. Université Laval, Quebec, pp. 367-374.

D'Amico, C., Gasparotto, G., Pedrotti, A., 1998. Scorie eneolitiche di Gaban e Acquaviva (Trento) caratteri, provenienza ed estrazione del metallo. In: D'Amico, C., Albore Livadie, C. (Eds.), Le Scienze della Terra e l'Archeometria. Istituto Universitario Suor Orsola Benincasa, CUEN Napoli, pp. 31-38.

Fasani, L., 1988. La sepoltura e il forno di fusione de La Vela Valbusa (Trento). Preistoria Alp. 24, 165-181.

Höppner, B., Bartelheim, M., Huijsmans, M., Krauss, R., Martinek, K.P., Pernicka, E., Schwab, R., 2005. Prehistoric copper production in the Inn Valley (Austria), and the earliest copper in central europe. Archaeometry 47, 293-315.

Horwitz, E.P., Chiarizia, R., Dietz, M.L., 1992. A novel strontium selective extraction chromatographic resin. Solvent Extr. Ion Exch. 10, 313-336.

Marzatico, F., 1997. L'industria metallurgica nel Trentino durante l'età del bronzo. In: Bernabò Brea, M., Cardarelli, A., Cremaschi, M. (Eds.), Le Terramare. La Più Antica Civiltà Padana, Catalogo Della Mostra. Electa, Milano, pp. 576-972.

Metten, B., 2003. Beitrag zur spätbronzezeitlichen Kupfermetallurgie im Trentino (Südalpen) im Vergleich mit anderen prähistorischen Kupferschlacken aus dem Alpenraum. Metalla 10,1-122.

Nimis, P., Omenetto, P., Giunti, I., Artioli, G., Angelini, I., 2012. Lead isotope systematics in hydrothermal sulphide deposits from the central-eastern Southalpine (northern Italy). Eur. J. Min. 24, 23-37. http://dx.doi.org/10.1127/09351221/2012/0024-216.

Pearce, M., 2007. Bright Blades and Red Metal. Essays on North Italian Prehistoric Metalwork. Accordia Specialist Studies on Italy, vol. 14. Accordia Research Institute, University of London.

Pedrotti, A., 2002. L'età del Rame. In: Lanzinger, M., Marzatico, F., Pedrotti, A. (Eds.), Storia del Trentino, La preistoria e la protostoria, 1. Il Mulino, Bologna, pp. 183-254.

Perini, R., 1971. I depositi preistorici di Romagnano - Loc (Trento). Preistoria Alp. 7, 7-106.

Perini, R., 1989. Testimonianze di attività metallurgica dall'Eneolitico alle fasi finali dell'Età del Bronzo nel Trentino. In: "Per Giuseppe Šebesta: scritti e nota biobibliografica per il settantesimo compleanno". Biblioteca Comunale di Trento, Trento, pp. 377-404.

Pernicka, E., Begemann, F., Schmitt-Strecker, S., Wagner, G.A., 1993. Eneolithic and Early Bronze Age copper artefacts from the Balkans and their relation to Serbian copper ores. Praehistorische Z. 68, 1-54.

Pernicka, E., F., Begemann, Schmitt-Strecker, S., Todorova, H., Kuleff, I., 1997. Prehistoric copper in Bulgaria: its composition and provenance. Eurasia Antiqua 3. 41-180.

Pernicka, E., Salzani, P., 2011. Remarks on the analyses and future prospects. In: Aspes, A. (Ed.), I bronzi del Garda. Memorie del Museo Civico di Storia Naturale di Verona, Verona, pp. 89-98.

Šebesta, G., 2000. La via del rame. Museo degli Usi e Costumi della Gente Trentina, S. Michele all'Adige.

Tecchiati, U., 1991. Praehistorische Bronzefunde conservati al Museo Civico di Rovereto (Trento): le asce. Ann. dei Musei Civici Rovereto 7, 3-36.

Tecchiati, U., 2009. Recenti ricerche sull'età del Rame in Val d'Isarco (Bolzano). Con un contributo di Lorna Anguilano sulle analisi chimico-petrografiche di scorie di fusione. In: Atti del 2 Congresso Internazionale «Ricerche paletnologiche nelle Alpi occidentali» in ricordo di Piero Barocelli e Osvaldo Coisson, Pinerolo, 17-19 Ottobre 2003.

Villa, I.M., 2009. Lead isotopic measurements in archeological objects. Archaeol. Anthropol. Sci. 1, 149-153.

Weisgerber, G., Goldenberg, G. (Eds.), 2004. Alpenkupfer - Rame Delle Alpi. Der Anschnitt, 17. Deutsches Bergbau Museum, Bochum.

Zammatteo, P., 2009. L'arte mineraria e la sua memoria in Trentino. Publistampa Edizioni, Pergine Valsugana. 